\title{
STUDENTS' PERCEPTION ON BLENDED LEARNING IN ENGLISH LISTENING AND SPEAKING CLASS
}

\author{
Magdalena Kartikasari Tandy Rerung* \\ English Language and Culture Department, Bunda Mulia University \\ Received on 2 October 2018 / Approved on 15 October 2018
}

\begin{abstract}
Nowadays, the communicative teaching has been influenced by the development of technology. Becoming interactive teacher would not be enough if it is not supported by technology usage. Online learning in this case has been a powerful tool to help language learners during their learning progress. It is said that that online instruction raised the good and average student's reading performance and the performance of the lowestperforming as well. In listening and speaking, online learning can help students improve their pronunciaton as well the comprehension skill. Therefore, the following study is designed to find out the students' perceptions towards the use of both online and face-to-face learning in listening and speaking classroom. There are 30 students from the $1^{\text {st }}$ and $3^{\text {rd }}$ semester of English Language and Culture Departement and they joined the class for 1 semester. Online learning platform used was taken from Cambridge Learning Management System integrated with Unlock 2 and Unlock 4 books as the source of learning. The result shows that most of the students see online learning as an alternative tool to help them during their learning process.
\end{abstract}

Keywords: blended learning, online learning, face-to-face learning, language learning

\begin{abstract}
ABSTRAK
Saat ini pengajaran dengan metode komunikatif dipengaruhi oleh perkembangan teknologi yang secara pesat. Untuk menjadi seorang pengajar yang interaktif, masih dirasa kurang tanpa ada dukungan dari pengggunaan teknologi. Di satu sisi, sistem pembelajaran jarak jauh (online learning) telah menjadi salah satu metode ajar yang dapat membantu pelajar untuk meningkatkan kualitas belajar mereka. Dikatakan pula bahwa pengajaran jarak jauh dapat meningkatkan performa belajar tidak hanya bagi para siswa yang pintar tetapi juga bagi para siswa yang kemampuan belajarnya masih rendah. Dalam kemampuan menyimak dan berbicara, sistem pembelajaran jarak jauh dapat membantu kemampuan cara ucap dan proses menyimak dalam Bahasa Inggris. Untuk itu, penelitian berikut ini ditujukan untuk mencari tahu persepsi para siswa selama mereka menggunakan metode pembelajaran jarak jauh dan kombinasinya dengan pertemuan di kelas. Penelitian ini mengambil 30 mahasiswa dari semester satu dan tiga dari jurusan Bahasa dan Budaya Inggris. Program ini sudah berlangsung selama 1 semester. Untuk penyedia sistem pembelajaran jarak jauh, penelitian ini menggunakan Cambridge Learning Management System yang berintegrasi dengan buku Unlock 2 dan Unlock 4. Hasil yang didapat menunjukkan bahwa sebagian besar mahasiswa menganggap bahwa sistem pembelajaran jarak jauh ini dapat membantu proses belajar mereka di kelas.
\end{abstract}

Kata Kunci: pembelajaran jarak jauh, pembelajaran tatap muka, pembelajaran bahasa

\section{INTRODUCTION}

\subsection{Background of the Study}

Blended Learning has become as an alternative way to teach English as a Foreign Language which is combined with Face-to-
Face classes with virtual learning experience in order to offer the students and teachers as well a wide range of materials and resources organized in a methodological way. The development of ELT methods and approaches have rapidly changed for decades and the

\footnotetext{
*Author(s) Correspondence:

E-mail: mrerung@bundamulia.ac.id
} 
needs of technology in education purpose has offered a new way in language teaching.

Traditionally, English teaching method was developed from face-to-face interaction in the teacher-centered classroom with the techniques in drilling, imitating, and so on. Then the method started to shift into the students-centered communicative teaching where the lessons were delivered more interactively and based on the learners' needs and styles of learning. Some techniques introduced in this area are problem solving, task-based learning, collaborative learning, and many more. Fortunately, with the emerging of internet and technology, it has successfully equipped students with more accessible materials and sources. Learning environment is not merely limited by indoor classroom; instead, it provides students with wider exploration in learning. This is the part where online leaning is taking part in students' learning experiences. One of the famous term is "blended learning" (BL).

Some research has been done in various contexts as well as to present some considerations during the designing, implementation and evaluation the blended learning program. The result supports and encourages teachers to reflect on Blended Learning (BL) as a potential and different way to approach EFL learners and to take advantage of all the emerging pedagogical tools.

The definitions of "blended learning", "face-to-face learning" and "online learning" vary a lot across different instructional contexts. In the present study, BL is defined as the combined instructional environment where face-to-face learning and online learning are mixed within a single teaching and learning environment. Face-to-face learning as mentioned earlier refer to traditional classroom instruction where instruction is given inside the classroom. Online learning, then, refers to web-based and self-directed learning either synchronously or asynchronously at computers. This involves the use of various virtual resources and tools such as online learning materials, chat, message boards, net meetings (Huang, 2016).
Furthermore, blended learning has emerged as one of the most popular pedagogical concepts in higher education from the beginning of 2000 (Halverson, 2014, cited in Huang, 2016). The term "blended learning" have been defined in many ways such as: "a combination of face-to-face and online learning, of technologies, of methodologies" (Oliver \& Trigwell, 2005), On the other hand, Osguthorpe and Graham (2003) defined blended learning as the combinaton of face-toface (f2f) with distance delivery systems, and the combination is suggested in three-models: "blend of activites", "blend of students in both face-to-face classroom and in online learning environment", "and blend of instructors through online learning environment".

In EFL setting, some research found some impacts regarding the language skill improvements. Al-Jarf (2005), based on his research concluded that online instruction raised the good and average students' reading performance and the performance of the lowest-performing as well. Another study conducted by Banados (2006, cited in Huang, 2016) implements a BL pedagogical model that included learners' work with English Online, online monitoring, Face-to-face classes and conversation classes. The results obtained by the pilot group showed a substantial improvement in the students' language skills. Other improvement can also be seen in Bruderman (2010, cited in Huang, 2016) in which he proposes the creation and implementation of an online peadagogical assistant as a Blended Learning device for ESP students. This action reseach resulted in students' progress in language skills and in recognizing their mistakes in English and correcting those mistakes by using the "online pedagogical assistant". In Taiwan, an action research was conducted by Liang and Bonk (2009, cited in Huang, 2016). It was aimed at acquiring English as a foreign language focused Blended Learning in order to encourage teachers to develop several strategies to implement and evaluate the teaching and learning process. The authors concluded that the combinations of BL are well adapted in EFL classes. It helps the

\footnotetext{
*Author(s) Correspondence:

E-mail: mrerung@bundamulia.ac.id
} 
students to use different virtual tools, and they are able to create significant interactions, especially with technology because they can take advantage of the available resources in many ways.

Furthermore, blended learning program has also been implemented in listening and speaking class by following the syllabus of the subject. The students have to accomplish tasks and assignments given either in the face-to-face classroom or through online. Sources given vary according to each lesson from visual to audio lessons. Furthermore, each lesson is also equipped with vocabulary games. Students have to accomplished the whole tasks to get the perfect score. Based on each unit, they can monitor the tasks they have accomplished and progress they have made. Listening and speaking skills are also one of the challenging skills faced by the students since they have to activate both skills whenever they are involved in the interaction in English setting. Blended learning at this point provides ways to explore various sources to increase their language skills, especially in listening and speaking. Teachers open an online source for each unit and instructs the students to complete the tasks before the next unit is unlocked. There are some students who seemed excited and decided to explore it before the classroom began. By looking at this phenomena, the researcher would like to find out how far this method interests them as EFL learners and what is the impact towards their language skills.

\subsection{Research Questions}

Based on several successful previous studies on Blended Learning program, the findings obtained from this study may contribute to the related literature through seeking answers to the following research questions:

1) What are the EFL learners' perceptions of blended learning approach?

2) What challenges do learners face when they apply blended learning approach?
3) Which of the two EFL teaching methods (traditional and blended) give results in their language skill performance?

\subsection{Significance of the Study}

The objective of this study is primarily to find out how far blended learning has been successful in giving impacts to the learners as well as in creating another learning environment based on the selected subject course. It may also to provide some perspectives in language learning especially in listening and speaking skills.

\section{LITERATURE REVIEW}

\subsection{Blended Learning Model}

Blended learning is a tool that helps students to explore their learning experience based on different interactive activities as an extension of the direct teaching classes. In this case, BL method guides students to organize their virtual experiences from different sources during their EFL learning process and also complement the face-to-face classes.

A blended model proposes by Khan (2005, cited in Alpala \& Flórez, 2011) consists of eight aspects which help this program be more organized and properly conducted. The diagram is shown as follows,

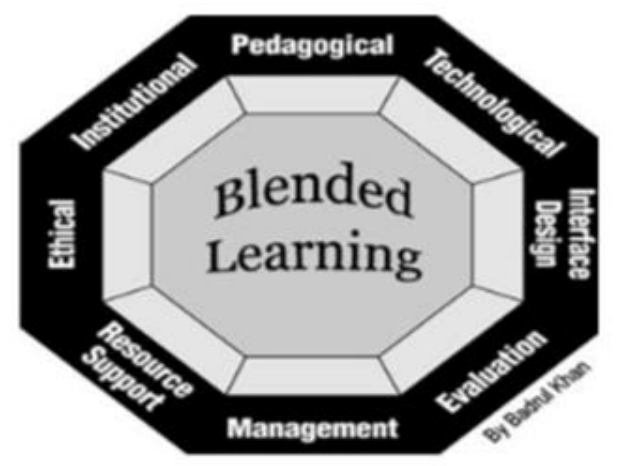

Figure 1. The Blended Learning Model (Khan, 2005)

\footnotetext{
*Author(s) Correspondence:

E-mail: mrerung@bundamulia.ac.id
} 
The first is "institutional aspect" which deals with the institutional policies about the curriculum, the layout of the material, and the administration and financial area. The program should be equipped with the training for technical purpose, technological resources, and based on the lesson plan of the courses.

The second is "technological aspect" which means that the resources should be taken from various display topics which will be limited in the physical classroom. Wider and more challenging resources will make lessons more interesting, and students might not get bored with the traditional method.

The third aspect is "pedagogical component", which specifies how the method can be blended well with face-to-face method which may later lead to the language learners' success in the learning process and in obtaining better results since they properly organize both components. According to Dudeney and Hockly (2007, cited in Alpala \& Flórez, 2011), there are some things to consider regarding the pedagogical implementation such as delivery mode, task design, materials, learners' and teachers' roles, tutors, assessment, and evaluation.

The fourth component discusses about "interface design" which deals on how the teachers can freely choose how the materials and sources being displayed online. Selection of the proper sources and materials should be in line with the lesson plan and students' needs and preferences. Therefore, it is important that the instructor designs the lesson based on the curriculum offered by the institution.

The last components are management, resource support and ethical aspects which are related to each other. In this case, the LMS (Learning Management System) works together in order to help students deal with the blended learning program. For example, the issues include how to $\log$ in, how to work on various assignments and how to apply learning strategies which are suitable to virtual environment. Other technical things also on how accessible the link given related to the topic and make sure the features are also friendly user. Lastly, since students will independently rely their knowledge on an open source such as Internet browsing activities, the system should also be able to detect any plagiarism acts which might happen during the process of learning.

\subsection{Blended Learning and Pedagogical Principles of EFL}

Huang (2016) gathered some sets of principles for effective teaching in EFL blended learning environments by synthesizing principles of good practice in undergraduate education. First is proposed by Chickering and Gamson (1987, cited in Huang, 2016) who offered seven principles for effective teaching in undergraduate education which highlight the importance of interaction between teacher and students, cooperation among students, support for students' active learning, prompt feedback, emphasis on time, communication of high expectations about students' learning and respect for students' diversity. Others is proposed by Garrison and Vaughan (2008, cited in Huang, 2016) which includes planning for the creation of open communication and trust, planting for critical reflection and discourse, establishing community and cohesion, establishing inquiry dynamics (purposeful enquiry), sustaining respect and responsibility, sustaining inquiry that moves to resolution and ensuring assessment is congruent with intended processes and outcomes.

On the other hand, aiming to establish a theory based on Communicative Approach (CA), Canale and Swain (1980, cited in Huang, 2016) proposed the five teaching principles, which are:

1. Facilitating the integration of grammatical, sociolinguistic and strategic knowledge without any overemphasis on one of those

2. Responding to the learners' communication needs

3. Providing learners with opportunities to take part in meaningful communicative interactions with highly competent speakers of the target language

\footnotetext{
*Author(s) Correspondence:

E-mail: mrerung@bundamulia.ac.id
} 
4. At early stages of second language learning, making optimal use of communicative competence that learners have developed in their first language that are common in the target language

5. Providing students with the information, practice and much of the experience needed to meet their communicative needs in the target language.

Ellis (2005) also added some principles for successful teaching as follows:

1. Ensure that students develop both a rich repertoire of formulaic expressions a rule-based competence.

2. Ensure that students focus on predominantly on meaning and form

3. Providing students with opportunities to participate in communicative activities in the target language, while not neglecting the need to develop their declarative knowledge of lexis, grammar, phonology, pragmatics and socio-critical features of target language.

4. Take into account learners' built-in syllabus.

5. Provide learners with extensive L2 input

6. Opportunities for output and to interact in the $\mathrm{L} 2$

7. Take account of individual differences in learners

8. Examine both the free and controlled production of students' language performances.

Based on the elaboration on some pedagogies in language teaching, there are some views that can be correlated with the blended learning program, specifically in EFL environment. Huang (2016) furthermore synthesized those into the following five pedagogical principles:

1. Create a supportive learning discourse

2. Promote students' collaborative learning and use of English for communication purposes.
3. Provide students' collaborative learning and use of English communication purposes.

4. Develop students' ability to take control of their own learning.

5. Enhance students' access to relevant language input and output.

It is suggested that teachers apply these five principles for both online and faceto-face instructions. Below is a table of some examples on how the pedagogical EFL teaching is reflected in the blended-learning program compared with the face-to-face classroom. The sets are proposed by series of activities suggested by some research adopted by Huang (2016) and taken from the series of activities suggested by Vaughan (2007) and Joosten, Barth, Harness and Weber (2013) or developed from findings of research on creating a motivating language classroom environment (Dörnyei, 2007), facilitating cooperative language learning and promoting student autonomy in language learning.

*Author(s) Correspondence:

E-mail: mrerung@bundamulia.ac.id 
Table 2.2 Pedagogical principles for EFL blended learning

\begin{tabular}{|c|c|}
\hline Principle & Face-to-face (examples) \\
\hline $\begin{array}{l}\text { 1. Create } \\
\text { supportive } \\
\text { learning } \\
\text { discourse so that } \\
\text { students feel } \\
\text { secure and } \\
\text { encouraged to } \\
\text { participate in } \\
\text { learning activities } \\
\text { and demonstrate } \\
\text { honestly their } \\
\text { own } \\
\text { understanding } \\
\text { and learning } \\
\text { needs }\end{array}$ & $\begin{array}{l}\text { - Explicitly introduce teaching } \\
\text { philosophy and expectation of } \\
\text { students' roles emphasising open } \\
\text { communication and contribution } \\
\text { - Encourage students to talk about } \\
\text { reasons, expectations and concerns } \\
\text { about the course } \\
\text { - Organise small group discussion } \\
\text { for students to get acquainted and } \\
\text { have some mutual understanding of } \\
\text { one another } \\
\text { - Take into consideration students' } \\
\text { affective factors to design } \\
\text { stimulating learning tasks and } \\
\text { encoura ge students' learning efforts } \\
\text { - Explicitly discuss the norms } \\
\text { regarding accepted behaviours in } \\
\text { both face-to-face and online } \\
\text { environments: openness, respect, } \\
\text { and critique with clues for } \\
\text { improvements }\end{array}$ \\
\hline
\end{tabular}

\section{Promote students' collaborative learning and use of English for communication purposes}

- students work collaboratively to achieve genuine communication purposes in English

- students work on learning tasks which require their cooperation
- Organise students to work in pairs and groups to practise using English for genuine communication

- Design pair and group work activities which requires students' positive interdependence: individual's goals can be attained when the goals of all members in the group are attained

- Explicitly discuss, analyse and demonstrate interpersonal and group working skills: communicate ideas clearly, respect others, maintain academic focus and manage conflict.

- Monitor students' collaborative work to give timely assistance

- Assess students' work in pairs and groups
Online (examples)

- Produce an introductory letter or a video clip to welcome students and inform them about teaching philosophy and expectations of students' roles.

- Create a bio page for students to post image and short bios of themselves

- Encourage students to contact teacher and peers using online communication tools

- Create Frequently Ask Questions (FAQ) online

- Make online contribution and obedience to the norms part of course requirement and course grade

- Participate in discussion thread, share knowledge and belief

- Respond to students who respond to you

-Provide a model of complying online etiquette

- Encourage students to communicate in English using asynchronous and synchronous communication tools

- Start discussion thread and require students' contribution

- Encourage students to share and contribute to peers' writing in target language.

- Provide model of successful collaborative work and analyse the benefits

- Be regularly present online but not take over the discussion; rather, provide synthesis and encouragement

*Author(s) Correspondence:

E-mail: mrerung@bundamulia.ac.id 


\begin{tabular}{|c|c|c|}
\hline Principle & Face-to-face (examples) & On line (examples) \\
\hline $\begin{array}{l}\text { 3. Provide } \\
\text { students with } \\
\text { timely and } \\
\text { constructive } \\
\text { feedback to } \\
\text { scaffold their } \\
\text { learning } \\
\text { individually }\end{array}$ & $\begin{array}{l}\text { Provide students with both } \\
\text { positive and error corrective } \\
\text { feedback with reference to } \\
\text { stated objectives, showing } \\
\text { progress and identify areas for } \\
\text { improvement and how to } \\
\text { improve } \\
\text { Require students to give } \\
\text { constructive feedback to their } \\
\text { peers } \\
\text { Encourage students' leaming } \\
\text { efforts }\end{array}$ & $\begin{array}{l}\text { - Utilise a utomatic assessment } \\
\text { tools to provide formative } \\
\text { feedback and recommended } \\
\text { learning mat crials } \\
\text { - Use onl ine records and } \\
\text { assessment features to gain } \\
\text { more understanding of students' } \\
\text { learning and provide them with } \\
\text { individually relevant feedback } \\
\text { via asynchronous } \\
\text { communication tools } \\
\text { - Respond to students' } \\
\text { contribution }\end{array}$ \\
\hline $\begin{array}{l}\text { 4. Develop } \\
\text { students' ability } \\
\text { to take control } \\
\text { of own learning: } \\
\text { facilitate } \\
\text { students' self- }\end{array}$ & $\begin{array}{l}\text { - Provide training in self-regulated } \\
\text { learning skills } \\
\text { - Be explicit about course } \\
\text { objectives and cnablestudents to } \\
\text { set up individual learning goals } \\
\text { aligning with course objectives }\end{array}$ & $\begin{array}{l}\text { - Post course syllabus and } \\
\text { objectives on LMS } \\
\text { - Encourage students to develop } \\
\text { list of individual course goals } \\
\text { using e-journal and cnable them } \\
\text { to review their list periodically }\end{array}$ \\
\hline $\begin{array}{l}\text { directed leaming } \\
\text { and reflection }\end{array}$ & $\begin{array}{l}\text { - Be explicit about learning } \\
\text { objectives, expected learning } \\
\text { out comes, methods and criteria for } \\
\text { assessment of individual learning } \\
\text { tasks } \\
\text { - Require students to pay attention } \\
\text { to teachers' feedback to pecrs and } \\
\text { reflect on own learning }\end{array}$ & $\begin{array}{l}\text { - Demonstrate examples of } \\
\text { satisfactory and unsatis factory } \\
\text { task performances and } \\
\text { encourage students' self- } \\
\text { assessment } \\
\text { - Provide and analyse examples } \\
\text { of self-regulated activities } \\
\text { - Give students a choice over } \\
\text { what, when and how to learn } \\
\text { while keeping to the overall } \\
\text { course goals }\end{array}$ \\
\hline $\begin{array}{l}\text { 5. Enhance } \\
\text { students' access } \\
\text { to rdevant } \\
\text { language input }\end{array}$ & $\begin{array}{l}\text { Assign appropriate learning } \\
\text { tasks for individual students in } \\
\text { class } \\
\text { Maximise the use of target } \\
\text { language but switch to first } \\
\text { language when necessary to } \\
\text { facilitate student's } \\
\text { comprehension }\end{array}$ & $\begin{array}{l}\text { Require students to reflect on } \\
\text { learning experience and take } \\
\text { learning preference inventory. } \\
\text { consider students' preferences } \\
\text { when designing course and } \\
\text { tasks } \\
\text { - Provide students with access } \\
\text { to a variety of learning } \\
\text { resources in different modes } \\
\text { (printed, audial, visual), types } \\
\text { (written, spoken) and at } \\
\text { different levels and encourage } \\
\text { them to make use of the } \\
\text { sources the way they like }\end{array}$ \\
\hline
\end{tabular}

Adopted from Huang (2016)

*Author(s) Correspondence:

E-mail: mrerung@bundamulia.ac.id 


\subsection{The Teaching of Listening and Speaking}

Richards (1988) views that listening has the purpose to understand the spoken discourse, which in this case is divided into two characteristics, which are top-down and bottom-up processing. These two different kinds of processes are involved in understanding spoken discourse.

Top-down refers to the use of background knowledge in understanding the meaning of the message. Background knowledge consists of context, that is, the situation and topic, and co-text, or in other words, what came before and after. For example, it is when one was listening to a friend's story and focusing more the whole topic of the story without paying attention to further details in the information.

Bottom-up, on the other hand, is the ability to separate the stream of speech into individual words in order to get engaged with specific details. For example, by remembering a certain instruction, numbers, names, and so on.

In reality, fluent listening normally depends on the use both processes operating simultaneously. If a person relies more on his/her knowledge, top-down ability is used. However, when a person listens more on the sound signal, bottom-up process is used. Furthermore, second-language listeners often revert to their knowledge of the topic and situation when faced with unfamiliar vocabulary or structures, so they use top-down processing to compensate for difficulties in bottom up processing. On the other hand, if a listener is unable to understand anything of what he/she hears, this person will not even be able to establish the topic of conversation, so top-down processing will also be very limited.

In the classroom activities, top-down activities are practiced in order to teach the learners' skills in making prediction based on the topic or situation, pictures, or key words. These techniques help them to develop their top-down processing skills. On the other hand, bottom-up activities will cover the whole details of the messages. Here, the language expressions are being introduced by learning the unfamiliar words and how to use them in specific situations.

Teaching speaking, on the other hand, also requires systemic procedures and strategic ways and unlike reading and writing, it happens in real life setting in which one speaker produces utterances based upon particular topics or situations and the other speaker tries to understand the utterances produced by the previous speaker and then show his/her responses. Thornburry (2007, cited in Ahmed, 2017) describes the process of developing skills as follows:

- Awareness; where teachers implant ideas that learners are entirely aware of the feature of the use of target language which is used as a channel of communication, conversation and commitment of something.

- Appropriation; the features of target language ensure appropriation and integration into the language the learners use for day to day conversation.

- Autonomy; reached when the students are able to use the language features in real life situations like interview, social interaction and classroom environment.

Furthermore, regarding speaking techniques, role plays and simulations are mostly applied as spoken practices in the classroom in any conversational setting. Nunan (2003, cited in Ahmed, 2017) argues that role-play is a type of acting in a real life situation designed by the teacher. In role play, learners are encouraged to use the target language because it resembles the real life situations. On simulations, it is actually a broader setting for role play where the individual participants speak and react as themselves with imaginary setting.

\section{RESEARCH METHOD}

The major objective of this research is to find out the learners' perceptions of blended learning, in comparison with the face-to-face learning especially for learners in higher

\footnotetext{
*Author(s) Correspondence:

E-mail: mrerung@bundamulia.ac.id
} 
education. Furthermore, when blended learning is used in teaching and learning, it can give rich experiences to both students and teachers.

Results in blended program will give further suggestion for not only students in the listening and speaking class, but also for teachers of other language skills to join the program and monitor the students' progress, not only in face-to-face interaction but also in online program. Using various approaches in language teaching will hopefully prepare the students to be able to use their English better. The online discussion forum and activities may also enable the students to improve their critical skills and linguistics competence.

\subsection{Research Design}

Present research study focused on the use of Learning Management System (LMS) designed by Cambridge for Listening and Speaking class for the first semester and third semester. The researcher applied mixedmethod based on the questionnaires and interviews. The books used in the classroom were Unlock $2\left(1^{\text {st }}\right.$ semester $)$ and Unlock $4\left(3^{\text {rd }}\right.$ semester) and the CEFR level is B1-B2 (high intermediate). Below is the sample of virtual display of the students' Cambridge LMS. The picture on the left side shows a list of tasks that students have to accomplish while the picture on the right side shows the result of students' progress.

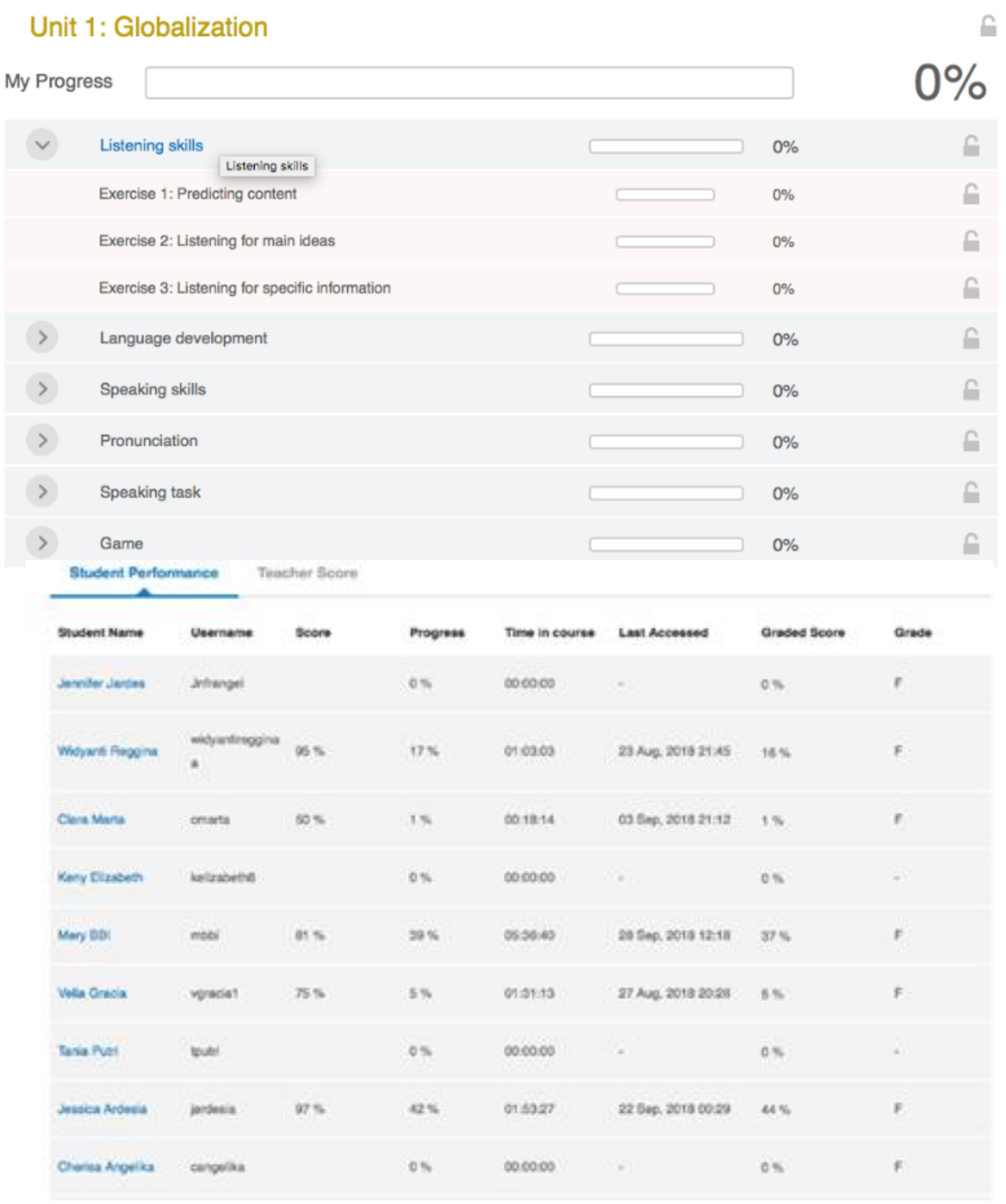

Figure 1. Sample of Cambridge LMS

*Author(s) Correspondence:

E-mail: mrerung@bundamulia.ac.id 


\subsection{Research Participants}

For the participants, this research selected $301^{\text {st }}$ and $3^{\text {rd }}$ semester students who are majoring in English Literature Department, which were taking the Listening and Speaking 1 and Listening and Speaking 3 class when this study commenced. The classes mostly focused on English usage in daily and academic setting which varies according to the topic of each lesson.

\subsection{Research Instruments}

In order to examine the participants' views regarding blended learning instruction, two questionnaires (for students and instructors) were distributed at the end of the semester. These questionnaires were adapted from Akkoyunlu \& Soylu (2008) which were originally designed to understand the perceptions of students and instructors regarding blended learning. There are 52 items for the students' questionnaire which focus on the perceptions of blended learning and its implementation process under 4 categories: (a) Online platform (b) Face-to-face sessions, (c) Assessment, and (d) Learners' views on blended learning in general.

\section{FINDINGS AND DISCUSSIONS}

Based on the results, there were thirty students responding to the questionnaires, and below is the first part which inquires about how the students can access the CLMS every time they want to do their task. For every item of the questions, the students have to choose from very easy (1) to very difficult (5). The result is as follows:

\begin{tabular}{|c|c|c|c|c|c|}
\hline \multicolumn{6}{|c|}{ Login } \\
\hline & & Frequency & Percent & Valid Percent & $\begin{array}{l}\text { Cumulative } \\
\text { Percent }\end{array}$ \\
\hline \multirow[t]{5}{*}{ Valid } & very easy & 5 & 16.7 & 16.7 & 16.7 \\
\hline & easy & 11 & 36.7 & 36.7 & 53.3 \\
\hline & difficicult & 11 & 36.7 & 36.7 & 90.0 \\
\hline & very difficult & 3 & 10.0 & 10.0 & 100.0 \\
\hline & Total & 30 & 100.0 & 100.0 & \\
\hline
\end{tabular}

\begin{tabular}{|c|c|c|c|c|c|}
\hline \multicolumn{6}{|c|}{ Instructions } \\
\hline & & Frequency & Percent & Valid Percent & $\begin{array}{l}\text { Cumulative } \\
\text { Percent }\end{array}$ \\
\hline \multirow[t]{5}{*}{ Valid } & very easy & 3 & 10.0 & 10.0 & 10.0 \\
\hline & easy & 10 & 33.3 & 33.3 & 43.3 \\
\hline & difficult & 15 & 50.0 & 50.0 & 93.3 \\
\hline & very difficult & 2 & 6.7 & 6.7 & 100.0 \\
\hline & Total & 30 & 100.0 & 100.0 & \\
\hline
\end{tabular}

\begin{tabular}{|c|c|c|c|c|c|}
\hline \multicolumn{6}{|c|}{ Exercises } \\
\hline & & Frequency & Percent & Valid Percent & $\begin{array}{c}\text { Cumulative } \\
\text { Percent }\end{array}$ \\
\hline \multirow[t]{6}{*}{ Valid } & very easy & 3 & 10.0 & 10.0 & 10.0 \\
\hline & easy & 6 & 20.0 & 20.0 & 30.0 \\
\hline & difficult & 19 & 63.3 & 63.3 & 93.3 \\
\hline & very difficult & 1 & 3.3 & 3.3 & 96.7 \\
\hline & cant access & 1 & 3.3 & 3.3 & 100.0 \\
\hline & Total & 30 & 100.0 & 100.0 & \\
\hline
\end{tabular}

\begin{tabular}{|c|c|c|c|c|c|}
\hline \multicolumn{6}{|c|}{ Completing } \\
\hline & & Frequency & Percent & Valid Percent & $\begin{array}{c}\text { Cumulative } \\
\text { Percent }\end{array}$ \\
\hline \multirow[t]{5}{*}{ Valid } & very easy & 5 & 16.7 & 16.7 & 16.7 \\
\hline & easy & 8 & 26.7 & 26.7 & 43.3 \\
\hline & difficult & 15 & 50.0 & 50.0 & 93.3 \\
\hline & very difficult & 2 & 6.7 & 6.7 & 100.0 \\
\hline & Total & 30 & 100.0 & 100.0 & \\
\hline
\end{tabular}

\begin{tabular}{|c|c|c|c|c|c|}
\hline \multicolumn{6}{|c|}{ Grades_Checking } \\
\hline & & Frequency & Percent & Valid Percent & $\begin{array}{c}\text { Cumulative } \\
\text { Percent }\end{array}$ \\
\hline \multirow[t]{6}{*}{ Valid } & very easy & 3 & 10.0 & 10.0 & 10.0 \\
\hline & easy & 5 & 16.7 & 16.7 & 26.7 \\
\hline & difficult & 15 & 50.0 & 50.0 & 76.7 \\
\hline & very difficult & 6 & 20.0 & 20.0 & 96.7 \\
\hline & cant access & 1 & 3.3 & 3.3 & 100.0 \\
\hline & Total & 30 & 100.0 & 1000 & \\
\hline
\end{tabular}

\begin{tabular}{|c|c|c|c|c|c|}
\hline \multicolumn{6}{|c|}{ Technical_issues } \\
\hline & & Frequency & Percent & Valid Percent & $\begin{array}{l}\text { Cumulative } \\
\text { Percent }\end{array}$ \\
\hline \multirow[t]{6}{*}{ Valid } & very easy & 3 & 10.0 & 10.0 & 10.0 \\
\hline & easy & 5 & 16.7 & 16.7 & 26.7 \\
\hline & difficult & 15 & 50.0 & 50.0 & 76.7 \\
\hline & very difficult & 6 & 20.0 & 20.0 & 96.7 \\
\hline & cant access & 1 & 3.3 & 3.3 & 100.0 \\
\hline & Total & 30 & 100.0 & 100.0 & \\
\hline
\end{tabular}

Figure 2. Results on accessibility to the Online Learning System

*Author(s) Correspondence:

E-mail: mrerung@bundamulia.ac.id 
Based on the result, it can be seen that most of the students did not have any serious difficulties while accessing the portal. During the login, more than half of the students think that the portal is easy to access $(53 \%)$. For reading the instructions, around $56 \%$ of the students think that it was quite difficult to follow. The reasons are probably since there were many tasks to do and the tasks were all different in variety. Each unit provides around 7 different tasks from reading to listening; therefore, students might think those all are somewhat complicated. The responses are also in line with the "exercise" result and also "completing". More than half of the students (nearly $70 \%$ ) think that those are difficult to do. For grades checking and technical issues, the students seem to have some difficulties in accessing the score even though through the front page of the portal, they can mostly view the whole personal information. This might be because they need more time to adjust on which part that they wanted to access.

\begin{tabular}{|r|r|r|r|r|r|r|r|r|r|}
\hline \multicolumn{2}{|c|}{ Statistics } \\
\hline
\end{tabular}

Figure 3. Results on Students Blended Learning Perceptions

Based on the second list of questionnaires, there are ten items asked in two broader categories. The first category asks about the positive influence of face-to-face learning towards the students' online learning while the second category asks about whether online learning gives positive influence to the students' face-to-face learning.

Looking from the mean results, most students answered "neutral to agree", and they perceived that face-to-face learning helps their online learning more, but not the other way around, which means that online learning does not provide much help for their face-to-face learning. The reasons might be due to the complexity of the platform and too many exercise tasks that they have to accomplish.

The last section of the questionnaire inquires about the students' perceptions toward face-to-face and online learning, and the result can be seen below:

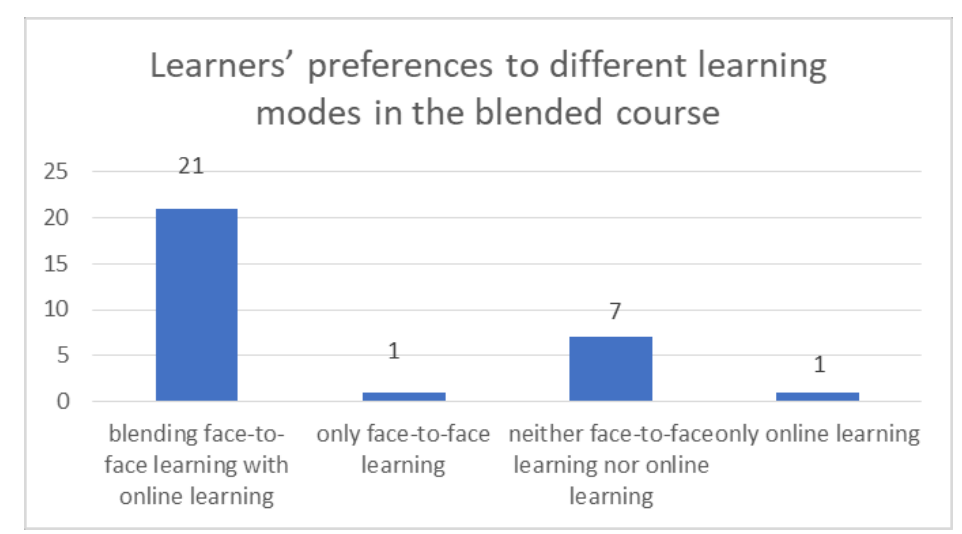

Figure 4. Results on Students Blended Learning and F2F Perceptions

*Author(s) Correspondence:

E-mail: mrerung@bundamulia.ac.id 
It is clear from the result that most of the students prefer to have both face-to-face learning and online learning. The questionnaires did not ask for the reasons in details, yet it might be because the students still dependently rely on their instructors more.

\section{CONCLUSIONS}

Based on the findings, it is shown that face-to-face learning still has an important role, especially in the students' learning process. On the other hand, online learning can be seen as a tool to help them practice the skills outside the classroom. In order to promote online learning and make it more effective, the teachers should present in details on how the students can make use the portal together with face-to-face learning equally. Online learning hopefully can gradually help the students to be independent learners. The teacher can also be a facilitator to assist and monitor students' discussion during the lesson. The lack of teacher's attention could probably demotivate students to work with the online learning; therefore, it is suggested that teachers can bring some feedbacks and reviews in the classroom, so the students can stay motivated.

\section{REFERENCES}

Ahmed, M. K. (2017). Pedagogy in speaking: Challenges addressed by teacher-student in the ESL context. International Journal of Applied Linguistics \& English Literature, 7(3), 97-107.

Akkoyunlu, B. \&. (2008). A study of students' perception in a blened learning learning environment based on different learning styles. Educational Technology \& Society, 11(1), 183-193.
Al-Jarf, S. R. (2005). The effects of online grammar instruction on low proficiency EFL college students' achievement. The Asian EFL Journal Quarterly, 7(4), 166-190.

Alpala, C. A. O., \& Flórez, E. E. R. (2011). Blended learning in the teaching of English as a foreign language: An educational challenge. HOW, A Colombian Journal for Teachers of English, 18(1), 154-168.

Dörnyei, Z. (2007). Research methods in applied linguistics: quantitative, qualitative, and mixed methodologies. Oxford: Oxford University Press

Huang, Q. (2016). Learners' perceptions of blended learning and the roles and interaction of $\mathrm{f} 2 \mathrm{f}$ and online learning. ORTESOL Journal, 33, 14-33.

Joosten, T. M., Barth, D., Harness, L., \& Weber, N. L. (2013) The impact of instructional development and training for blended teaching on course effectiveness. In A. G. Picciano, C. D. Dziuban, \& C. R. Graham (Eds.), Blended learning: Research perspectives, Volume 2 (pp. 173-189). New York \& London: Routledge Ltd.

Oliver, M., \& Trigwell, K. (2005). Can 'blended learning' be redeemed?. ELearning, 2(1), 17-26.

Osguthorpe, R. T., \& Graham, C. R. (2003). Blended learning environment: Definitions and directions. The Quarterly Review of Distance Education, 4(3), 227-223.

Richards, J. (1988). Designing instructional materials for teaching listening comprehension. University of Hawai'i Working Papers in English as a Second Language, 7(1).

Vaughan, N. D. (2007). Perspectives on blended learning in higher education. International Journal on E-Learning, 6(1), 81-94

\footnotetext{
*Author(s) Correspondence:

E-mail: mrerung@bundamulia.ac.id
} 